\title{
Mining legacy of Colorado recorded in the sediment of drinking water reservoirs in New Mexico
}

Christina L. FERGuson ${ }^{1}$, JOHANNA M. BlaKE ${ }^{2}$, AND JEB BROWN ${ }^{3}$

${ }^{1} 6700$ Edith Blvd NE Albuquerque, NM 87113; cferguson@usgs.gov

${ }^{2} 6700$ Edith Blvd NE Albuquerque, NM 87113; imtblake@usgs.gov

${ }^{3} 6700$ Edith Blvd NE Albuquerque, NM 87113; jebbrown@usgs.gov

The Animas River has its headwaters in the highly mineralized zones near Silverton, CO. This area was actively mined from the late 1800's until 1991 when all mining operations ceased. Sediment from two drinking water reservoirs in northern New Mexico, both supplied by the Animas River, was collected and analyzed for metals through bulk chemistry, mobility experiments, and scanning electron microscopy to determine if the sediment provides a record of upstream mining activity. Four trenches were excavated in the drained Aztec Reservoir in May 2018 and four cores were collected from Farmington Lake in November 2019. Results from the Aztec Reservoir sediments indicate elevated concentrations of uranium, vanadium, arsenic, and copper in the lowest (oldest) samples. Agedating of these sediments using ${ }^{137} \mathrm{Cs}$ indicates that these elevated concentrations correspond to the pre1972 time period during which mining and milling practices included release of waste directly into the river. Preliminary handheld X-ray fluorescence results from Farmington Lake sediments show elevated concentrations of strontium, titanium, and zirconium. The results from the chemical analysis of the sediment at both sites aid in understanding metal deposition and mobility in the reservoirs. This information will ultimately inform land managers and water system operators about sediment geochemistry in drinking water reservoirs with contributions from upstream legacy mining. 